\title{
The Ambivalent Legacy of Minority Protection for Human Rights
}

\author{
Emmanuel Dalle Mulle, Mona Bieling
}

Most historiographical currents examining the history of human rights postulate a clear break between the collective rights tradition of interwar minority protection and the ensuing age of individual human rights. Two observations, however, suggest a more nuanced account of the transition from the League of Nations' to the United Nations' rights systems. First, the minority treaties were a hybrid system containing a mix of individual and collective rights provisions that enabled interwar rights advocates to use them as a model for the adoption of human rights instruments. Second, at the end of WWII, several delegations at the UN strongly defended the inclusion of elements of interwar minority protection within the Genocide Convention (GC) and the Universal Declaration of Human Rights (UDHR). Although these efforts were unsuccessful, they show that there was no consensus in favour of an exclusively individualist conception of human rights. More importantly, opposition to the inclusion of minority protection clauses came from Western diplomats who defended their governments' prerogative to promote the assimilation of the people inhabiting their territory into the majority culture of the state. Therefore, what prevailed during the drafting process of the GC and the UDHR was an assimilationist interpretation of human rights; one that in a context of national heterogeneity promised to favour the rights of some groups (national majorities) over those of others (national minorities).

As other young fields of research, the history of human rights has been occupied with issues of genealogy. ${ }^{1}$ When and where human rights originated is the question that has driven research in this area of study for the last two decades, leading to polarisation and, more recently, timid efforts at reconciliation. ${ }^{2}$

A first wave of critical human rights historiography questioned early scholarship on human rights as a teleological tale of unlimited progress since the dawn of ancient religious and philosophical traditions. These early works singled out the immediate post-WWII years as the moment when human rights were enshrined in international law through their inclusion in the Charter of the United Nations and the Universal Declaration of Human Rights. ${ }^{3}$ Mark Mazower, in particular, has skilfully portrayed the Great Power interests behind the

1 The authors would like to thank the Swiss National Science Foundation for its generous support (grant n. 169568) and Davide Rodogno, Börries Kuzmany, Marina Germane, Yvette Issar and the two anonymous reviewers of the Schweizerische Zeitschrift für Geschichte for their insightful comments on previous versions of this paper.

2 For the latter see Stefan-Ludwig Hoffmann, Human Rights and History, in: Past \& Present 232/1 (2016), pp. 279-310.

3 See Elizabeth Borgwardt, A New Deal for the World: America's Vision for Human Rights, Cambridge 2007; Mary Ann Glendon, A World Made New: Eleanor Roosevelt and the Universal Declaration of Human Rights, New York 2001. For notable exceptions see Lynn Avery Hunt, Inventing Human Rights: A History, New York 2007. 
"triumph» of human rights and opened the way to a refreshing new perspective on the until then rather celebratory human rights literature. ${ }^{4}$ At the same time, his view of the "triumph" of individual human rights ${ }^{5}$ overly emphasises both the collective nature of the interwar rights system established by the League of Nations and the individualist one of the UN rights regime. Generally, Mazower's and other works that focus on the 1945 break suggest «a vacuum of rights initiatives in the inter-war period ${ }^{6}$ and propose a so-called "Big Bang Theory» of human rights. ${ }^{7}$ In these accounts, the system of minority protection supervised by the League of Nations during the European interwar years is represented as being incompatible with human rights. The former is seen as encompassing collective rights, while the latter is conceived of as having an exclusively individual character. ${ }^{8}$

In a more recent version of such a "Big Bang Theory», Samuel Moyn has set the clock forward three decades and declared the mid-1970s as the birthdate of international human rights, meant as rights that go beyond the nation-state. Moyn asserts that between 1945 and 1975, human rights were prominent for their marginality within international law debates and practices, rather than for their omnipresence. He argues that the «mystery of the 1940s is not why human rights emerged, but - given future developments - why they failed to do so". ${ }^{9}$ Furthermore, contrary to what Mazower and others have proclaimed, Moyn has questioned the individualist nature of the UDHR. He rather argues that the UDHR was built on a "personalist» understanding of human rights, rooted in the Christian concept of human dignity and in a communitarian view of individuals not as atomised entities, but as members of moral collectivities. ${ }^{10}$ Yet, in line with Mazower, Moyn insists that after 1945, human rights had no connection to interwar minority rights in their "general public meaning». ${ }^{11}$

Several authors have recently begun reassessing the place of minority rights in the wider history of human rights, challenging the sharp dichotomy between interwar minority protection and post-1945 human rights made in earlier works.

4 Mark Mazower, The Strange Triumph of Human Rights, 1933-1950, in: The Historical Journal 47/2 (2004), pp. 379-398.

5 See also Gerald Daniel Cohen, The 'Human Rights Revolution' at Work: Displaced Persons in Postwar Europe, in: S.-L. Hoffmann (eds), Human Rights in the Twentieth Century, Cambridge 2011, pp. 45-60; and Borgwardt, op. cit., pp. 58-59.

6 Miaa Halme-Tuomisaari, Pamela Slotte, Revisiting the Origins of Human Rights: Introduction, in: P. Slotte, M. Halme-Tuomisaari (eds), Revisiting the Origins of Human Rights, Cambridge 2015, p. 6.

7 Idem.

8 See Christian Tomuschat, Human Rights: Between Idealism and Realism, Oxford 2014, pp. 1724 ; Borgwardt, op. cit., pp. 58-59.

9 Samuel Moyn, The Last Utopia: Human Rights in History, Cambridge 2010, p. 68.

10 Samuel Moyn, Personalism, Community, and the Origins of Human Rights, in: S.-L. Hoffmann (eds), op. cit., pp. 85-106.

11 Moyn, The Last, op. cit., pp. 252-253, note 17. 
While Dzovinar Kévonian has cast a new light on the contribution of interwar legal experts to the early internationalisation of human rights (or rather the rights of man ), ${ }^{12}$ James Loeffler has compellingly shown how Jewish rights activists and organisations continued to fight for the infusion of elements of minority protection into the coming human rights regime until the late $1940 \mathrm{~s}^{13}$ Joining such growing body of scholarship, this article makes two interconnected arguments to provide a more nuanced interpretation of the transition from the League's to the UN's rights system.

First, the article dissects the ambivalent ways in which interwar minority protection informed post-1945 human rights. On the one hand, minority protection displayed obvious flaws that the international legal scholars contributing to the establishment of the UN rights regime tried to avoid. One of these flaws was the asymmetrical application of internationally guaranteed rights to some countries and some categories of individuals only. On the other hand, the minority treaties contained a hybrid collection of rights mixing individual and collective provisions. As we will show below, these provisions enabled interwar rights advocates to use the universalist provisions contained in them as a model for the adoption of human rights instruments.

Second, the article stresses the continuing currency of some of the most distinctive elements of interwar minority protection during the negotiations of the Genocide Convention and the UDHR. This is exemplified by the efforts of delegates of the Soviet bloc, joined by several Asian and Middle Eastern representatives, who strove to obtain the inclusion of an article on cultural genocide in the Genocide Convention, as well as of provisions on protection against assimilation within the Declaration. Although these delegates did not manage to pass their amendments, their attempts to include provisions for collective rights are an unmistakable reminder that, despite the failure of the League's system, some clauses of interwar minority protection still enjoyed support among a substantial share of state representatives in the late 1940s. ${ }^{14}$

More importantly, these official debates reveal a key and oft-overlooked feature of the early UN rights system: opposition to the inclusion of minority

12 Dzovinar Kévonian, Mémoire inédit: The Swing of the Pendulum: Les juristes et l'internationalisation des droits de l'homme, 1920-1939, Lyon 2018. See also: Helmut Philipp Aust, From Diplomat to Academic Activist: André Mandelstam and the History of Human Rights, in: European Journal of International Law 25/4 (2014), pp. 1105-1121; Barbara Metzeger, League of Nations, Refugees and Individual Rights, in: Matthew Frank, Jessica Reinisch (eds), Refugees in Europe, 1919-1959: A Forty Years' Crisis?, London 2017, pp. 101-120.

13 James Loeffler, Rooted Cosmopolitans: Jews and Human Rights in the Twentieth Century, New Haven 2018, pp. 113-168. See also Nathan Kurz, Jewish Internationalism and Human Rights after the Holocaust, Cambridge 2020, pp. 19-38.

14 This has also been noticed by Inis Claude, National Minorities: An International Problem, New York 1955, pp. 144-175; and, more recently, by Johannes Morsink, The Universal Declaration of Human Rights: Origins, Drafting, and Intent, Philadelphia 2010, pp. 269-280. 
protection clauses came from Western diplomats who defended their governments' prerogative to promote the assimilation of the people inhabiting their territory into the majority culture of the state. Far from embodying a purely individualist conception of human rights, these delegates deliberately defended an assimilationist conception of human rights; one that privileges the rights of some groups (national majorities) over those of others (national minorities).

Before elaborating on these two sets of arguments in detail, we briefly describe the main features of the League's minority system.

\section{The Minority Rights System of the League of Nations}

At the Paris Peace Conference, the negotiating powers settled on self-determination as the main principle of political legitimacy in the international arena. ${ }^{15}$ Accordingly, state borders were to be redrawn, as much as possible, along nationality lines. While there were many violations of the principle of self-determination during the peace negotiations, its discursive strength was not diminished. Still, peacemakers were confronted with a dilemma as boundaries and "politically significant identities» did not always overlap. ${ }^{16}$ As a consequence, diplomats at Versailles faced the existence of national minorities within countries defining themselves as nation-states.

The Great Powers saw three solutions to this perceived dilemma: moving borders, eliminating minorities (mostly through transfers of populations), or giving minorities some protection within the state in which they happened to live. The third option tended to prevail. The peace negotiators devised a minority rights system that granted protection by means of a mix of negative and positive rights to national minorities in some selected countries whose main goal was to preserve peace and stability on the Eastern part of the continent after the ravages of the Great War. ${ }^{17}$ The Great Powers assumed that, by embracing some of their demands, individuals belonging to a national minority would accept membership of and be loyal to states dominated by a majority they did not identify with. ${ }^{18}$

The first of the minority treaties was the Treaty between the Principal Allied and Associated Powers and Poland, signed on 28 June 1919, which served as a model for the following minority treaties. By 1924, the system concerned 15

15 Erez Manela, The Wilsonian Moment: Self-Determination and the International Origins of Anticolonial Nationalism, Oxford 2007, p. 5.

16 Jennifer Jackson Preece, National Minorities and the European Nation-States System, Oxford 1998, p. 11.

17 Carole Fink, The Paris Peace Conference and the Question of Minority Rights, in: Peace \& Change 21/3 (1996), p. 280.

18 Jackson Preece, op. cit., p. 11. 
countries, 50 minorities and 30 million people. ${ }^{19}$ The Polish Treaty contained 12 articles. Articles 1 to 7 recognised basic civil liberties such as «full and complete protection of life and liberty to all inhabitants» and the free exercise of «any creed, religion or belief», as well as the principle of non-discrimination. Articles 8 to 11 provided for measures of positive discrimination protecting members of minority groups against assimilation. Article 12 established the League of Nations' international guarantee of the provisions targeting minorities. This meant that the countries concerned could not change these minority clauses (inscribed in their constitutions) without the agreement of the League's Council, and that the League had a duty to ascertain compliance with the treaties. ${ }^{20}$ The treaties thus "provided for three categories of rights: rights accruing to all citizens of a State, such as equal legal protection and a right to nationality; rights accruing to all inhabitants of a State, such as full protection of life and liberty; and rights of a minority group in particular, such as freedom of religion and freedom of education $»{ }^{21}$ The system was made up of two main pillars: On the one hand, minorities were granted equality before the law through general rules of non-discrimination extended to the entire population of the country. On the other hand, they were guaranteed special measures of protection against assimilation. ${ }^{22}$ Some minor differences notwithstanding, the same provisions appeared in all treaties.

Apart from the extensive nature of the clauses imposed on the new states, the great novelty of the minority system was the collective international guarantee entrusted to the League of Nations. For the first time, an international organisation could limit the freedom of a state to deal with its own citizens. ${ }^{23}$ As argued by Kate Parlett, the treaties «gave individuals international protection against treatment by their own state» and «represented a significant incursion into the traditional reserve of domestic jurisdiction, in a way which is analogous to the operation of post-1945 human rights law».24 The drafters of the treaties devised a complex formulation whereby individuals were endowed with selected rights, however, they only qualified for protection as members of a minority. Hence, apart from a few provisions (notably article 10 of the Polish Treaty), the

19 Carole Fink, Defending the Rights of Others: The Great Powers, the Jews, and International Minority Protection, 1878-1938, Cambridge 2006, pp. 211-280.

20 Carole Fink, The Paris, op. cit., pp. 281-283; Jackson Preece, op. cit., pp. 75-76.

21 Catherine Brölmann, The PCIJ and International Rights of Groups and Individuals, in: C. Tams, M. Fitzmaurice (eds), Legacies of the Permanent Court of International Justice, Leiden 2013, p. 127.

22 Partick Thornberry, Is There a Phoenix in the Ashes? International Law and Minority Rights, in: Texas International Law Journal 15/3 (1980), pp. 432-433.

23 Brölman, op. cit., pp. 128.

24 Kate Parlett, The Individual in the International Legal System: Continuity and Change in International Law, Cambridge 2013, p. 338. 
treaties granted collective, not corporate rights ${ }^{25}$ and, as argued by Natasha Wheatley, "the laws required a group subject and obliterated it at the same time». ${ }^{26}$

Individual members of minorities (as well as minority organisations) could send petitions to the League drawing the body's attention to any violations of the treaties. Such petitions, however, only had an informative character and could not force the League's Council to take any action. Upper Silesia was a notable exception. The German-Polish Accord did endow individuals with a right to petition that had to be treated by the local Minorities Office and a Mixed Commission. Individuals and organisations could also directly appeal to the Council of the League. ${ }^{27}$ In 1945, looking back at the Upper-Silesian experiment, the Foreign Office civil servant John Mabbot commented that, all its limitations notwithstanding, «no international settlement of the consequences of territorial changes was ever made with so much attention to the human elements involved. Never before did the attempt go so far to secure individual rights and protect them internationally». ${ }^{\mathbf{2 8}}$

The League's minority system had major weaknesses that would ultimately undermine its legitimacy. From the perspective of the Great Powers, the true purpose of the system was not so much the protection of national minorities, but rather the preservation of peace and stability within and between European nation-states. Minority protection was therefore often implicitly understood as a temporary measure to assuage minorities while preparing the ground for their assimilation. ${ }^{29}$ Although this might have been an advantage for the states these minorities lived in and the Great Powers, it increased minorities' anxiety about their own destiny, with destabilising effects on majority-minority relations and, therefore, on the same peace and stability for which protection was sought. The system also had important operational shortcomings. The procedure for the evaluation of petitions was often too long and cumbersome, very rarely reaching

25 Corporate rights are attributed to a group subject (for instance a corporation, a cultural council or a religious community). This means that the group itself, separately from its individual members, is the bearer of rights. Collective rights, by contrast, are attributed to individuals and not groups, but such individuals hold them because they are members of a specific group. Individual rights are those who are held by individuals as such. On the distinction between corporate, collective and individual rights and whether collective rights can be considered human rights see Peter Jones, Human Rights, Group Rights, and Peoples' Rights, in: Human Rights Quarterly 21/1 (1999), pp. 80-107.

26 Natasha Wheatley, Spectral Legal Personality in Interwar International Law: On New Ways of Not Being a State, in: Law and History Review 35/3 (2017), p. 777.

27 Parlett, op. cit., p. 77.

28 Quoted in Brian Simpson, Human Rights and the End of Empire: Britain and the Genesis of the European Convention, Oxford 2001, p. 142.

29 Carol Weisbrod, Minorities and Diversities: The Remarkable Experiment of the League of Nations, Connecticut Journal of International Law 8 (1992), p. 368; Fink, Defending, op. cit., p. 273; Paul Smith, Stanislav Sierposwski, Minorities in the System of the League of Nations, in: P. Smith (eds), Ethnic Groups in International Relations, Aldershot 1991, p. 15. 
the League's Council. ${ }^{30}$ The League also had little leverage to enforce compliance with the treaties, since it depended too much on the Great Powers' will to guarantee respect of the rules. ${ }^{31}$

The one weakness of the system that had the greatest influence on the formation of the future UN rights system, however, was a dual asymmetry in its nature, which we explore in the following section.

\section{The Minority System: Dual Asymmetries and Human Rights Potential}

The first asymmetry of the League's minority system was external. The minority treaties applied only to a stretch of Eastern European countries from the Baltic to Turkey (and, from 1932 onwards, Iraq). These countries highly resented being singled out for such a lesson in «international deportment». ${ }^{32}$

At Versailles, the Great Powers were highly aware of the inconsistency of their position. For example, Sir James Headlam-Morley, British member of the Committee on New States, pointed out early on that «my own feeling is that we cannot ask other nations to accept principles which we would not be prepared to see applied to ourselves», ${ }^{33}$ a position predictably shared by the leaders of the states that were forced to accept the minority treaties. At a plenary session of the Peace Council, on 31 May 1919, the Polish Prime Minister Jan Paderewski argued that Poland was ready to «accord to all its citizens 'all the liberties which have already been or may be granted to them by the Great Nations and States of the West' and would 'amplify' them 'to the same degree' as all members of the League of Nations» (our emphasis). ${ }^{34}$ In a letter to Paderewski that accompanied the Polish Treaty, the Allied and Associated Powers argued that they were establishing the best possible system for ensuring collective security given the circumstances. However, the Powers were in fact imposing rules on the new states that they themselves were not ready to respect. ${ }^{35}$ The lack of generalisation of minority protection was certainly not the only reason for the system's eventual

\footnotetext{
30 Brölman, op. cit., p. 130, note 32.

31 Christian Raitz von Frentz, A Lesson Forgotten. Minority Protection under the League of Nations. The Case of the German Minority in Poland, 1920-1934, Munster 1999, p. 234; Carole Fink, Minority Rights as an International Question, in: Contemporary European History 9/3 (2000), p. 391.

32 Mark Mazower, Minorities and the League of Nations in interwar Europe, in: Daedalus 126/2 (1997), p. 53. This asymmetry clearly reflected civilisational stereotypes according to which the Great Powers considered the new Eastern European states as not sufficiently mature to be able to treat their national minorities appropriately without international supervision.

33 Quoted in Alan Scharp, Britain and the Protection of Minorities, in: A. Hepburn (eds), Minorities in History, London 1978, p. 182.

34 Quoted in Fink, Defending, op. cit., p. 233.

$35 \quad$ Ibidem., p. 233-234.
} 
demise. Yet, it deeply undermined the treaties' legitimacy and directly contributed to the system's collapse in 1934, when the Polish Minister of Foreign Affairs, Colonel Jozef Beck used it as an excuse to declare its country's commitments null and void "pending the introduction of a general and uniform system for the protection of minorities». ${ }^{36}$

Taking this weakness into account, after WWII, none of the delegates in San Francisco proposed that the coming multilateral rights system should be based upon regional instruments. In his 1945 An International Bill of the Rights of Man, which served as an inspiration for the first draft of the UDHR, the leading international jurist Hersch Lauterpacht made clear that a similar mistake could not be repeated. He wrote that the Bill of Rights «eliminates one of the principal drawbacks of the system of protection of minorities as established by the treaties of 1919. It applies universally to all States and thus removes a frequently voiced objection by the States which were asked to subscribe to them ${ }^{37}$

The second asymmetry of the League's minority system was internal. The treaties singled out one category of people for international protection and left the rest unprotected. In East-West Street, Philippe Sands vividly describes the destructive potential of this type of asymmetry. He recalls how Juliusz Mackarewicz, a Polish lawyer and nationalist politician, principal author of the Polish criminal code, «detested the 1919 Polish Minorities Treaty because it discriminated against Poles. Minorities could complain to the League of Nations if their rights were violated, but Poles couldn't» (emphasis in the original). ${ }^{38}$ After WWII, the Director of the New York Institute of Jewish Affairs, Jacob Robinson, called this feeling «the resentment of majorities in regard to minorities» adding that «under the old system a privileged position was allegedly granted to ethnic minorities by providing them with a right of recourse to an international forum [...] The establishment of a universal bill of rights would remove any such alleged discrimination at a single stroke». ${ }^{39}$ The perception that the treaties had given a «privileged» position to national minorities contributed to forming a widespread consensus about the need to base the new rights system on universal rights for all.

These two asymmetries of interwar minority protection influenced the formation of the UN rights system by showing approaches to the international protection of rights and the preservation of peace and stability that had to be avoided. At the same time, the minority treaties possessed potential for the protection of human rights that is often overlooked in the literature on the history of

36 Quoted in Jackob Robinson [et al.], Were the Minorities Treaties a Failure?, New York 1943, pp. 178-179.

37 Hersch Lauterpacht, An International Bill of the Rights of Man, Oxford 2013 [1945], p. 152.

38 Philippe Sands, East West Street on the Origins of Genocide and Crimes Against Humanity, London 2016, p. 250.

39 Robinson [et al.], op. cit., p. 137. 
human rights, notably the articles guaranteeing rights to all citizens of the state..$^{40}$ For example, Article 7 of the Polish Treaty (which was the model for all the other minority treaties) related to the first pillar of minority rights, namely nondiscrimination. It established that «all Polish nationals shall be equal before the law and shall enjoy the same civil and political rights without distinction as to race, language or religion». ${ }^{41}$ Furthermore, article 2 asserted that «Poland undertakes to assure full and complete protection of life and liberty to all inhabitants of Poland without distinction of birth, nationality, language, race or religion ${ }^{42}$ The potential for universal human rights represented by these two articles of the minority treaties was stressed throughout the interwar years by one of the most important legal experts on the issue of minorities of the time, André Mandelstam. As a pioneering scholar and rights campaigner, his work, which stresses the complementarity of minority rights and human rights, warrants a closer look.

\section{André Mandelstam : From Minority to Human Rights}

A former Russian diplomat, Mandelstam became a prominent legal expert and supporter of human rights in interwar Paris. He belonged to a group of interwar intellectuals, such as Albert de La Pradelle and Boris Mirkine-Guetzévitch, who strove to obtain recognition for the position of the individual in international law. As argued by Dzovinar Kévonian, collectively, these intellectuals prepared the ground for the later "transition from minority rights to human rights».43

Mandelstam himself did not see any contradiction between minority and human rights, but rather understood them as being complementary and advocated for a transition from minority to human rights that built on provisions already existent in the minority treaties. He thought that the minority treaties had created «different human rights, under the form of rights of inhabitants, citizens and members of minorities».44 In particular, article 2 of the Polish Treaty referred to all inhabitants and article 7 to all citizens. In accordance with article 1 , these clauses had the status of fundamental law within the signatory states

40 For exceptions see Jan Herman Burgers, The Road to San Francisco: The Revival of the Human Rights Idea in the Twentieth Century, in: Human Rights Quarterly 14/4 (1992); Kévonian, The Swing, op. cit.; Aust, op. cit.

41 Treaty between the Principal Allied and Associated Powers and Poland [henceforth Treaty with Poland], 28 June 1919, http://ungarisches-institut.de/dokumente/pdf/19190628-3.pdf (29.03. 2021).

42 Treaty with Poland, art. 2.

43 Dzovinar Kévonian, André Mandelstam and the Internationalization of Human Rights (18691949), in: M. Halme-Tuomisaari, P. Slotte (eds), op. cit., p. 255.

44 André Mandelstam, La Generalisation de la Protection Internationale des Droits de l'Homme, in: Revue de Droit International et de Legislation Comparée 11/3 (1930), p. 298. 
and, therefore, offered an «internal guarantee» whereby they overruled all other laws, regulations or official actions in conflict with them. Some limitations notwithstanding, according to Mandelstam, the League's minority system «could be qualified as a veritable human law (droit humain) limiting state sovereignty to the advantage of the individual».45 As a consequence, Mandelstam argued that "the protection of human rights found itself considerably enlarged as compared with the age before the War».46

In the early 1920s, Mandelstam had pleaded for the generalisation of the minority system..$^{47}$ However, after the 1925 debate in the Assembly of the League of Nations during which France and the UK strongly opposed any proposals in favour of such generalisation, he grew sceptical of this option. Mandelstam then pushed for a convention on the rights of man that would base its work on the human rights principles already enshrined in the minority treaties..$^{48} \mathrm{He}$ thought that this would assuage the Great Powers' fear that the extension of the minority clauses would be exploited by ethnic entrepreneurs to create minority questions where they did not previously exist.

Mandelstam tried to realise his advocacy plans through his membership of two authoritative interwar legal institutions: the Institut de droit international (International Law Institute, IDI), a club gathering some of the world's most distinguished jurists with the aim to contribute to the development of international law; and the Académie diplomatique internationale (International Diplomatic Academy, ADI), a body founded in 1926 in Paris with the goal to become a leading institute devoted to the study of global affairs. In the late 1920s, Mandelstam managed to convince the IDI to adopt a declaration of the rights of man and the ADI to pass a resolution in favour of the establishment of a world convention on the rights of man. Although the two documents had different impacts, Mandelstam was the driving force behind both. These documents warrant closer attention as they show how he attempted to realise his ideas.

The first document was the IDI's Declaration of the Rights of Man (1929) composed of six articles that heavily borrowed from the minority treaties. ${ }^{49}$ Mandelstam was the rapporteur of the Commission in charge of preparing the first draft of the declaration. In his commentary, he constantly related all the articles of the IDI's text to the minority treaties, thus revealing how important a reference they were for him. While article 1,2 and 4 broadly speaking reproduced the right to life and freedom, the right to non-discrimination and the religious freedom enshrined in articles 2 and 7 of the Polish Treaty, article 3 of this

45 Mandelstam, La Generalisation, op. cit., p. 299.

46 Ibidem., p. 300.

47 André Mandelstam, La protection des minorités, Leiden 1923, pp. 499-510.

48 Mandelstam, La Generalisation, op. cit., p. 705.

49 See André Mandelstam, La Déclaration des droits internationaux de l'homme adoptée par l'Institut de Droit International, in: Esprit international 4/14 (1930), pp. 59-78. 
new declaration forbade any restrictions «against the free use, by anybody and in any way, of the language of his choice, or against the teaching of this one».50 Finally, by asserting in article 5 that «the equality foreseen shall not be nominal, but effective», ${ }^{51}$ the Declaration incorporated elements of the jurisprudence of the Permanent Court of International Justice (PCIJ), which had determined that the rights set out in the treaties would need to be protected effectively.52

Given the IDI's authoritative status, Mandelstam believed that the Declaration would become an indirect source of international law; ${ }^{53}$ however, this was wishful thinking. While the IDI's Declaration was known in some intellectual circles at the time, it did not reach as wide an audience as Mandelstam would have hoped and there is no evidence that it directly influenced the drafting of the UDHR. ${ }^{54}$ Although many factors influenced this outcome, according to Dzovinar Kévonian, the relative fall into oblivion of the Declaration was mainly due to the damnatio memoriae that hit Mandelstam (and by consequence the document that bore his imprint) after his defence, in 1937, of the Italian colonisation of Ethiopia. ${ }^{55}$

The second document that Mandelstam influenced considerably was the Resolution passed by the Académie diplomatique internationale (ADI) in 1928 in favour of the establishment of a world convention on the rights of man. On the basis of a draft proposed by Mandelstam, the ADI's resolution recalled that the minority treaties had bound «a certain number of States to respect the rights of men and citizens» and, building on the provisions of articles 2 and 7 of the Polish Treaty, expressed «the hope that a world convention may be drawn up under the auspices of the League of Nations, ensuring the protection and respect of such rights».56 Although less elaborate than the IDI's declaration, the ADI's text enjoyed some more resonance, at least after its initial release. In the early

50 Institut de droit international (IDI), La Déclaration des droits internationaux de l'homme, 12 October 1929, art. 3.

$51 \quad$ Ibidem., art. 5.

52 See Aust, op. cit., p. 1112.

53 Mandelstam, La Déclaration, op. cit., p. 60.

54 However, the IDI's Declaration did appear in the Analysis of Various Draft International Bills of Rights prepared by the Division on Human Rights for the discussion of the draft UDHR. See UN Doc. E/CN.4/W.16.

55 Kévonian, The Swing, op. cit., p. 402. Mandelstam's critique of the condemnation of the Italian invasion of Ethiopia built on the alleged «human rights» argument that slavery was a legal practice in Ethiopia. Mandelstam accused the League of hypocrisy, since this organisation had not applied sanctions in previous cases of human rights violations (for example against Soviet Russia or Nazi Germany) or breaches of state sovereignty (among others during the Polish-Soviet War in 1920). Mandelstam's arguments showed deep-seated racist thinking whereby «developed states» (such as Italy) were thought to be hierarchically superior to «underdeveloped states» (in this case Ethiopia) on account of civilizational differences and were therefore entitled to violate state sovereignty and put the latter under tutelage.

56 Quoted in Antoine Frangulis, Les Droits de l'homme et du citoyen devant l'Assemblé de la Société des Nations, Paris 1933. 
1930s, the ADI's 1928 Resolution reappeared in a session of the Assembly of the League of Nations that addressed a case of discrimination by Nazi authorities against a German citizen of Jewish origin, Franz Bernheim, and triggered an intense debate on the internationalisation of human rights.

\section{Human Rights at the League of Nations}

In May 1933, Franz Bernheim, who was resident in the Upper-Silesian city of Gleiwitz, petitioned the League for violation of the non-discrimination and general rights of man clauses of the German-Polish Accord on East Silesia. At the end of April, the company he worked for had discharged him on account of anti-Semitic legislation. Bernheim's petition called for the repeal of a series of discriminatory measures adopted by the Nazis, the reinstatement of all people affected in their rights and adequate compensation. In June 1933, the German Foreign Minister reassured the Council of the League that international legality would be restored, which occurred a year later, when the German Upper Silesian President Helmuth Brückner suspended the application of Nazi anti-Semitic legislation in the region. ${ }^{57}$ At the $14^{\text {th }}$ session of the League of Nations' Assembly, in September-October 1933, the Bernheim case generated a heated discussion within the Sixth Committee. The League's "victory» - in this specific instance to counter the openly discriminatory measures of the German government exposed, at the same time, the main limitation of the system, i.e. its restriction to only a few countries. If the Upper-Silesian rules had been imposed on all of Germany, maybe Jews and other targeted groups there could be defended as well. ${ }^{58}$ Hence, giving voice to the stream of thought led by Mandelstam, the Haitian delegate and ADI's member Antoine Frangulis filed a draft resolution reproducing the ADI's 1928 text, which called for the adoption of a convention on the rights of man based on articles 2 and 7 of the Polish Treaty. ${ }^{59}$

Some delegates showed interest in the idea of establishing such a convention and engaged in human rights language. The Irish envoy was in favour of studying the possibility of a general convention on human rights. Speaking on

57 Franz Bernheim eventually received a compensation of 1,600 marks in December 1935 and his precedent was later applied to several other Germans of Jewish descent.

58 A similar argument was made 15 years later by French jurist René Cassin in a speech at the Commission on Human Rights in charge of negotiating the UDHR. Cassin, who participated in the 1933 debates on the Bernheim petition as a member of the French delegation, lamented that Hitler could take advantage of the Third Reich's «absolute sovereignty» to fend off any League of Nations' infringement into its domestic affairs. Statement by René Cassin, Representative of France, on the Implementation of Human Rights, Commission on Human Rights, 15 June 1948, E/CN.4/147.

59 Burgers, op. cit., p. 457. Kévonian however reveals how among Frangulis' purposes there was also that of attracting the public opinion's attention on the Academy and the Dictionnaire Diplomatique that it had just published. She therefore defines the Declaration as, at least in part, the result of a "political marketing» strategy. Kévonian, The Swing, op. cit., pp. 308-310. 
behalf of Czechoslovakia, Edvard Beneš mentioned that «the cultural, political and economic life of a minority can only prosper in a country where the principle of the French Revolution - that of the rights of men and citizens - [...] and the principle of respect for human personality form the legal basis of every citizen's daily life ${ }^{60}{ }^{60}$ According to the jurist Nikolaos Politis, who represented Greece, the best solution "would consist of a combined system which would retain, as a general regime applicable to all countries, recognition of the rights of man whether member of a majority or of a minority».61 Finally, the French representative claimed to speak in the name of «the principles at the basis of [the French] Revolution which proclaimed the rights of man and of citizens without distinction of race, religion or origin ${ }^{62}$ Yet, despite entertaining the idea to begin discussing a human rights convention, the Assembly eventually only approved a declaration expressing the hope that states not bound to the minority treaties would ensure that their minorities enjoyed the same guarantees requested by the treaties.

Neither the IDI's 1929 Declaration, nor the ADI's 1928 Resolution managed to trigger the transition from the asymmetrical minority protection system of the League of Nations to the universal human rights regime that André Mandelstam had striven to bring about. The failure of this attempt at reform notwithstanding, Mandelstam's engagement, along with that of other jurists of the time whom we did not focus on here for reasons of scope $-{ }^{63}$ bears witness to the potential for the development of human rights contained in the minority treaties. Contrary to the view prevalent after the Second World War, and repeated by part of the literature on the history of human rights, whereby there exists a stark contrast between interwar minority protection and post-war human rights, interwar human rights supporters called for a recalibration of the system in the form of a universalisation and expansion of already existing provisions guaranteeing individual rights for all rather than for an outright rejection of provisions in favour of minorities. ${ }^{64}$

60 League of Nations (LoN), Official Journal, Special Supplement 120, p. 40.

61 Ibidem., p. 52.

62 Ibidem., p. 49.

63 For more information on these jurists see Kévonian, The Swing, op. cit. We chose to focus on Mandelstam because, more than any other, he strove to find theoretical and practical solutions to the tension between individual and collective rights in a context of incipient expansion of international law.

64 Documents similar to the IDI's declaration and the ADI's resolution were adopted by the InterParliamentary Union in 1923 and discussed at length within the Federation of League of Nations' Societies in 1933. 
James Loeffler and Nathan Kurz have convincingly argued that, contrary to previous interpretations, ${ }^{65}$ Jewish activists and organisations continuously supported the inclusion of clauses protecting minorities against assimilation well into the late 1940s. ${ }^{66}$ The current historiography, however, has overlooked an important line of fracture within the incipient UN rights system, which becomes clear when looking at the drafting process of the Genocide Convention (GC) and the Universal Declaration of Human Rights (UDHR) from 1946-1948. The negotiations of these two documents saw two groups confronting each other. The first group (mostly composed of Latin American, Anglo-Saxon and Western European countries) opposed the inclusion of an article on cultural genocide in the Convention and of protection against assimilation in the Declaration. The second group, on the contrary, (represented by the Soviet Bloc along with some Asian and Middle Eastern states) was in favour of adding collective rights provisions to both texts in order to ensure better protection for the members of specific groups.

The analysis of the drafting of the GC and the UDHR reveals not only that within the international community of states there was more support for protection against assimilation than is usually portrayed. It also, and more importantly, shows that delegates resisting the inclusion of clauses on protection against assimilation based their position on an explicit claim that governments needed to be free to coerce minorities into adopting the majority's culture, rather than on a supposedly individualist principle of non-discrimination. Even authors such as Samuel Moyn, who have questioned the historiographical cliché of a 1945 transition to an individualist conception of rights, have missed the fact that what prevailed at the UN between 1946 and 1948 was an assimilationist conception of rights that favoured some groups (national and cultural majorities) over others (national and cultural minorities).

\section{The Genocide Convention and Legitimate Homogenisation}

As mentioned in the introduction, the immediate post-WWII period is often celebrated as the time of the triumph of individual human rights. Ironically, such alleged triumph was inaugurated by a convention defending the rights of groups. Although it is not obvious that contemporary actors understood the Genocide Rights at the 1946 Paris Peace Conference, in: Simon Dubnow Institute Yearbook 15 (2016), pp. 187-209. 
Convention as part of the body of human rights legislation as we do today, ${ }^{67}$ the Convention ensures a right to existence of (minority) groups ${ }^{68}$ and, therefore, it covers much of the ground of article 2 of the Polish minority treaty, which guaranteed all inhabitants of Poland «full and complete protection of life and liberty ... without distinction of birth, nationality, language, race or religion ".69 Protection under the Convention is a minimum but legally binding one against extreme cases of violence. The Convention focuses on the destruction of individuals as members of a specific group rather than as individuals «as such».

The term genocide did not exist before 1944, when it was first proposed by the Jewish-Polish lawyer Raphael Lemkin. Having lived in interwar Poland, Lemkin was influenced by the context of the minority treaties and the following Nazi crimes. Lemkin defined genocide as «a coordinated plan of different actions aiming at the destruction of essential foundations of the life of national groups, with the aim of annihilating the groups themselves.$^{70}$ Quite importantly, he identified a number of «techniques», beyond physical annihilation, that would lead to the disappearance of the group and that were carried out in the political, social, cultural, economic, religious and moral fields. ${ }^{71}$

The Convention uses the term "groups» rather than «minorities» regarding who should be protected. The context of the Convention as well as the summary records of its drafting sessions leave few doubts, however, that what the delegates had in mind were mostly minorities. Examples of «slips of the tongue» during the drafting process abound. ${ }^{72}$ Similarly, the whole discussion about cultural genocide that we examine below was interpreted, by several delegates, as coinciding with the field of minority protection. The delegates preferred using the term "groups" over that of «minorities» because the former allowed prosecuting cases in which the targeted group would in fact be a numerical majority. Yet, diplomats were aware that, in most instances, the persecuted group would be a minority. ${ }^{73}$

The drafting process of the Genocide Convention, as well as the parallel debate on the Universal Declaration of Human Rights, offer an invaluable view-

67 Raphael Lemkin himself, the inventor of the term genocide, is believed to have questioned this. See Moyn, The Last, op. cit., p. 82; Tanya Elder, What You See Before Your Eyes: Documenting Raphael Lemkin's Life by Exploring his Archival Papers, 1900-1959, in: Journal of Genocide Research 7/4 (2005), p. 486.

68 Thornberry, op. cit., p. 444; Yoram Dinstein, Collective Human Rights of Peoples and Minorities, in: International \& Comparative Law Quarterly 25/1 (1976), p. 105.

69 Treaty with Poland, art. 2.

70 Raphael Lemkin, Axis Rule in Occupied Europe, Washington 1944, p. 79.

71 Ibidem., p. 82. See also William Schabas, Genocide in International Law: The Crimes of Crimes, Cambridge 2000.

72 See for instance the speech of the Egyptian delegate in UN Doc. A/C.6/SR.65, All the documents listed henceforth can be found through the code cited at https://documents.un.org/prod/ods. nsf/home.xsp (29.03.2021). 
point to observe the understandings of individual and collective rights that were defended at the time by different state delegations. That is why we take a closer look at both in the following paragraphs.

The process that led to the adoption of the Convention began in December 1946. That month, UN Resolution 96(I) defined genocide as «a denial of the right to existence of entire human groups ${ }^{74}$ and called on the Economic and Social Council (ECOSOC) to prepare a convention on the subject. In March 1948, ECOSCOC created an Ad Hoc Committee tasked with formulating a draft later to be submitted to the Commission on Human Rights. ${ }^{75}$ During the drafting process, discussions about the opportunity to introduce some elements within the text that had characterised interwar minority protection centred around the crime of cultural genocide, which Lemkin considered key for the protection of groups. ${ }^{76}$ The Ad Hoc Committee formulated cultural genocide as follows:

In this Convention genocide also means any deliberate act committed with the intent to destroy the language, religion or culture of a national, racial or religious group on grounds of national or racial origin or religious belief such as:

1. prohibiting the use of language of the group in daily intercourse or in schools, or the printing and circulation of publications in the language of the group;

2. destroying, or preventing the use of, libraries, museums, schools, historical monuments, places of worship or other cultural institutions and objects of the group. ${ }^{77}$

Within the Ad Hoc Committee (composed of delegates from China, France, Lebanon, Poland, the US and the USSR), only the French and US representatives opposed inclusion of an article on cultural genocide; hence, the clause was retained. ${ }^{78}$ The Commission on Human Rights did not have time to discuss the Committee's draft and ECOSOC dealt with it very quickly. Then, in October 1948, the text arrived at the $6^{\text {th }}$ Committee of the General Assembly, where the key discussion over the draft convention took place. There, two groups with opposing views became apparent.

The delegates making up the first group mainly came from Latin American, Anglo-Saxon and Western European states. Many of these countries had substantial immigrant communities and some were still colonial powers with extensive empires. In the debates over the Genocide Convention, they opposed the inclusion of an article on cultural genocide for two main reasons. First, they sug-

\footnotetext{
74 UN Resolution 96(I), 11 December 1946.

75 Thornberry, op. cit., pp. 64-67.

76 Schabas, op. cit., p. 180. See also, Devin O. Pendas, Toward World Law? Human Rights and the Failure of the Legalist Paradigm of War, in: S.-L. Hoffmann (eds), Human Rights in the Twentieth Century, Cambridge 2011, p. 224.

77 E/794, p. 17.

78 E/AC.25/Sr.14.
} 
gested that including such a measure would stretch the concept of genocide too wide and that the issue should be dealt with in the framework of the UDHR. Accordingly, the French delegate filed an amendment proposing that the attention of the Third Committee (in charge of discussing the draft UDHR) should «be drawn to the need for the protection of language, religion and culture within the framework of the International Declaration of Human Rights». ${ }^{79}$ His Belgian colleague was more explicit and proposed to omit article 3 «with a view to inclusion among provisions for the protection of human rights» ${ }^{80}$ Such proposals suggest that the delegates saw the two documents to be interrelated with each other as parts of a wider system of rights-protection mechanisms. However, their arguments were disingenuous, since a specific article on protection against assimilation had already been deleted from the draft UDHR four months earlier, in June 1948 (as we will see below). Second, the group that withstood the inclusion of an article on cultural genocide feared that such a legal provision could forbid states to adopt any policy of assimilation altogether. The Brazilian delegate, in particular, declared that to «achieve by legal means a certain degree of homogeneity and culture within its boundaries ${ }^{81}$ was a legitimate end that could be hampered by article 3. In a hyperbolic statement, his Swedish counterpart feared that his country could be held responsible for cultural genocide because it had converted the Lapps to Christianity. ${ }^{82}$

The second group, led by the representatives of the Eastern Bloc joined by some Middle Eastern and Latin American delegates, held that cultural genocide had to be addressed in the Convention since a group could be destroyed even without the physical elimination of its members. Hence, it was necessary to protect the group's key characteristics. The delegate of Pakistan suggested that «the chief motive of genocide was a blind rage to destroy the ideas, the values and the very soul of a national, racial or religious group, rather than its physical existence. Thus, the end and the means were closely linked: cultural genocide and physical genocide were indivisible». ${ }^{83}$ Similarly, Egypt's envoy accused some colonial powers of substituting «their own culture for the ancient one respected by the local population" and concluded that the Convention was the only way to protect the latter. ${ }^{84}$ These efforts notwithstanding, article 3 on cultural genocide was eventually rejected by 25 votes to 16 , with 4 abstentions. ${ }^{85}$

79 A/C.6/SR83, p. 200. The representatives of India, Uruguay, Great Britain, Brazil, New Zealand, The Netherlands and Iran made similar comments.

80 A/C.6/217.

81 A/C.6/SR83, p. 197. The Brazilian concern had a longer genealogy, since it was in line with statements made by the Brazilian representative Franco de Mello in the Assembly of the League of Nations in 1925. See Fink, Defending, op. cit., p. 297.

82 A/C.6/SR83, p. 197.

83 Ibidem., pp. 193-194.

84 Ibidem., p. 199. See also the intervention of the Belarusian delegate at pp. 201-202.

85 A/C.6/SR83, p. 206. 
When the Convention was adopted at the last debate in the plenary session of the General Assembly, in December 1948, the Soviet delegate, backed by the Pakistani and Venezuelan delegates, made a final attempt to include cultural genocide in the text.86 During that discussion, the US envoy "agreed that it was difficult to reply to the eloquent arguments of the representative of the USSR, Venezuela and Pakistan $»{ }^{87}$ however, he insisted that physical and cultural genocide were completely different categories and the latter concerned «the fundamental rights of the individual». ${ }^{88} \mathrm{~A}$ number of other representatives maintained that the cultural protection of groups had to be assured within the framework of the UDHR, which, however, by then, had already been deprived of a specific article on minorities. The USSR's amendment was eventually repealed by 31 votes to 14 , with 10 abstentions.

The negotiations of whether an article addressing cultural genocide should be included in the Convention show a divide in opinions between opponents and supporters of adopting specific measures for the cultural protection of groups. Several delegates built their arguments against protection against assimilation on the idea that states had a right to promote, through legitimate means, the assimilation of the individuals living within their borders. Such an idea featured even more prominently in the discussions over the Universal Declaration of Human Rights.

\section{The UDHR and the Assimilation of Groups}

The drafting of the Genocide Convention occurred almost simultaneously to the drafting of the UDHR. In the latter negotiations a similar dispute between opponents and supporters of protection against assimilation emerged even more clearly than in the talks on the Convention. The clash between these two groups was not only a struggle between a conception of human rights that included collective provisions defending the cultural specificities of minorities and a view of human rights as belonging to abstract individuals removed from their cultural context, but also, and especially, a conflict about the legitimacy and suitability of assimilation in which an assimilationist conception of human rights eventually prevailed.

Minority rights in the UDHR are defended only by means of the first pillar of minority protection, namely the principle of non-discrimination. Yet, since the beginning of the drafting process efforts were made to include an article on protection against assimilation. The initial text prepared by John Peter Hum-

\footnotetext{
86 A/PV.179, pp. 814-819.

87 Ibidem., p. 821.

88 Idem.
} 
phrey (Director of the Division of Human Rights within the UN Secretariat) contained the following provision:

In states inhabited by a substantial number of persons of a race, language, or religion other than those of the majority of the population, persons belonging to such ethnic, linguistic, or religious minorities shall have the right as far as compatible with public order and security to establish and maintain schools and cultural or religious institutions and to use their own language in the Press, in public assembly and before the courts and other authorities of the State. ${ }^{89}$

Humphrey had turned to Lauterpacht's International Bill of the Rights of Man for inspiration. In his commentary to the Bill, Lauterpacht argued in favour of the inclusion of an article on protection against assimilation because «the claim of the individual to the preservation and development of his ethnic identity by at least some education in his native language and by being allowed to use it before the administrative and judicial authorities of the state and to maintain the cultural institutions of his ethnic group cannot be disregarded without doing violence to a principle of justice and stultifying human personality».90

In a prescient remark made during the work of the Drafting Committee in charge of preparing a first version of the Declaration, the Lebanese delegate Charles Malik observed that the substance of the article on protection against assimilation «seemed to be what divided the New World and the Old. In the Old World, there were wide divisions of ethnic groups. In the New World, there was assimilation ". ${ }^{91}$ Yet, Malik's comment overlooked the fact that several Western European governments, notably France, eventually rallied behind the position of their New World's counterparts.

The Soviet Union was the staunchest supporter of including an article on protection against assimilation within the Declaration. In light of the USSR's poor record in the treatment of minorities in the early 1940s, when entire groups accused of collaboration with the Nazi enemy were deported from border areas to Central Asia and Siberia, where they were then subjected to policies of forceful assimilation, ${ }^{92}$ it is legitimate to wonder why Moscow persisted in this commitment. Archival records suggest that the Soviet position was based on considerations of both ideology and power politics. On the one hand, the Soviet conception of human rights emphasised collective (notably economic and social, but also cultural) rights over individual rights. Furthermore, albeit widely violated in practice, Soviet nationality policy, whereby national cultures were offi-

\footnotetext{
89 E/CN.4/AC.1/3/Add.1, p. 380.

90 Lauterpacht, op. cit., p. 153.

91 E/CN.4/AC.1/SR.15, p. 6.

92 See Francine Hirsch, Empire of Nations: Ethnographic Knowledge and the Making of the Soviet Union, Ithaca 2005, pp. 307-308.
} 
cially recognised (in some cases even actively created) and allowed to flourish, ${ }^{93}$ was a pillar of the USSR's domestic legal system. It should not be surprising that the Soviet leadership wanted to project this flagship policy abroad during the construction of the new post-WWII international order. ${ }^{94}$

On the other hand, Moscow also deliberately used minority protection as a weapon against the United States and colonial powers in the incipient Cold War; a weapon that could be quite effective, as suggested by a US internal document of January 1947 acknowledging that race discrimination against black people and the treatment of Native Americans could invite international intervention. ${ }^{95}$ This strategic use of minority protection, however, does not mean that its defence on the part of the USSR was necessarily disingenuous, since criticising race discrimination in the US and denouncing prolonged British and French imperial rule were in line with official Soviet ideology. ${ }^{96}$

The inclusion of an article on the protection of minorities against assimilation was debated at different moments throughout the drafting process of the UDHR. The first important discussion occurred in December 1947, within the Working Group on the Declaration of Human Rights. Eleanor Roosevelt opened the floor claiming that a clause on protection against assimilation was not necessary as other articles already ensured this specific protection. She further cited the 1938 Conference of Lima where it stated that «a system of protection of ethnic, linguistic or racial groups could not be supported in America, where minorities did not exist as such $" .^{97}$ By contrast, the Belarusian representative, backed by his Soviet counterpart, proposed adding a reference to territorial autonomy and to the need to provide minorities with public funds to ensure their rights. Not being able to find an agreement, the Working Group decided to postpone any decision on the matter..$^{98}$

The introduction of an article on the protection of minorities against assimilation was discussed again at the third session of the Commission on Human Rights, in June 1948. Chairwoman Roosevelt reasserted that "minority questions did not exist on the American continent» and stressed how «United States experience with foreign groups residing within its borders had been happy, assim-

93 Ibidem., pp. 1-18.

94 Anna Lukina, Soviet Union and the Universal Declaration of Human Rights. Max Planck Institute for European Legal History Research Paper Series, January 2017.

95 Anton Weiss-Wendt, The Soviet Union and the Gutting of the UN Genocide Convention, Madison 2017, p. 117.

96 The true inconsistency lay in the gap between the Soviets' international defence of minority protection and its disregard for the rights of some domestic minorities. To explain this contradiction, Anton Weiss-Wendt argues that «by collectively labelling certain minority groups 'traitors to the motherland', Stalin's regime effectively removed them from a universe of obligation". Ibidem., pp. $78-79$.

97 E/CN.4/AC.2/SR.9, p. 5.

98 Ibidem., pp. 17-21. See also E/CN.4/57; E/CN.4/95. 
ilation having been emphasized throughout»(our emphasis).99 She further repeated that the substance of the article could be covered by reference to the rights and freedoms set forth in the Declaration. Once again, the opposite position was defended by communist countries. The Ukrainian delegate explained that «a statement of rights of individuals to free development without discrimination» could not defend minorities because «for example, the article concerning education ensured the right to education; it did not ensure the right of a member of a special group to be educated in his own language». ${ }^{100}$

Trying to find a compromise between the American and Ukrainian positions, Charles Malik suggested declaring that «cultural groups shall not be denied the right to free self-development», but his proposal was rejected. ${ }^{101}$ Eventually, the Commission on Human Rights decided by 10 votes to 6 not to include a clause on protection against assimilation within the UDHR. ${ }^{102}$ Supporters of an assimilationist conception of human rights (mostly delegates from Latin American, Anglo-Saxon and Western European countries) won out. The French representative Pierre Ordonneau concisely conveyed this group's position when he commented that «the historical development of France into a homogenous State had resulted from the extensive and rigorous application of universal human rights to all sections of the population» (our emphasis). ${ }^{103}$

Twice before the final approval of the Declaration, advocates of the inclusion of a clause on the protection of minorities against assimilation tried, in different ways, to reinstate an article on the matter in the Declaration: at the Third Committee of the General Assembly between September and December 1948; and at the plenary session of the Assembly on 10 December of the same year.

Within the Third Committee, the USSR representative tabled an amendment that attempted to make protection against assimilation less obviously linked with minorities by stating that «all persons, irrespective of whether they belong to the racial, national or religious majority of the population, have the right to their own ethnic or national culture». ${ }^{104}$ Denmark and Yugoslavia also submitted similar texts. ${ }^{105}$ Once again, the contrast between supporters and opponents of measures against assimilation came to the fore when discussing these proposals. According to the Brazilian delegate, if the state allowed immigrants to speak their tongue, they would have no interest in learning the language of their new state. ${ }^{106}$ Moreover, in a badly disguised apology for colo-

\footnotetext{
99 E/CN.4/SR.73, p. 5.

100 E/CN.4/AC.2/SR.9, p. 10.

101 E/CN.4/SR.74, p. 2.

102 Ibidem., p. 5.

103 E/CN.4/SR.73, p. 12.

$104 \mathrm{E} / 800$.

105 A/C.3/307/Rev.1/Add.1.

106 GAOR, SR161, p. 721.
} 
nialism, the French representative, René Cassin, warned that the USSR's amendment jeopardizes the "emancipation" of communities in the French colonies, by which he meant that protecting local languages would risk cutting off colonised people from French culture and society. ${ }^{107}$

The Soviet delegation made yet another attempt to introduce an article on protection against assimilation at the plenary meeting of the UN General Assembly in December 1948. ${ }^{108}$ As all previous efforts, this came to nought. A specific measure on protection against assimilation, modelled on the HumphreyLauterpacht text, would appear about twenty years later in article 27 of the International Covenant on Civil and Political Rights. The three delegations that more than any other had tried to include a minority provision within the UDHR - the USSR, Yugoslavia and Lebanon - had somehow mismanaged their cards by not better coordinating their action. Their insistence on defending the inclusion of such an article, however, bears witness to the continuing currency of some elements of interwar minority protection among a substantial share of UN delegates in the late 1940s. More importantly, Western delegates defended the legitimacy of states to pursue the non-violent assimilation of the populations living on their territory, thus marking the «triumph» of an assimilationist conception of human rights.

\section{Conclusion}

It is often argued that the failure of the League of Nations' minority rights system explains why specific measures on protection against assimilation were not included in the UDHR. Nevertheless, this is inconsistent with the fact that countries such as Czechoslovakia, Poland and Yugoslavia, which were under the jurisdiction of the treaties during the interwar years, supported the introduction of such provisions within the Declaration. ${ }^{109}$ The opposition between the American and the Soviet blocs in the incipient Cold War, based both on ideology and realpolitik, accounts for much of this unexpected outcome. The defence of minority protection was consistent with the ideological underpinnings of the Communist conception of human rights, which privileged collective over individual provisions. In the case of the USSR, it was also in line with her flagship although often violated - nationality policy enshrined in the 1936 Constitution. ${ }^{110}$ The USSR, as well as the US for that matter, adopted a position of

107 Ibidem., p. 723.

108 See A/784; GAOR, SR.182, p. 900; GAOR, SR.183, pp. 913-914.

109 William Schabas, Les droits des minorités: Une déclaration inachevée, in: Commission nationale consultative des droits de l'homme (eds), La Déclaration universelle des droits de l'homme, 1948-98: Avenir d'un idéal commun, Paris 1999, pp. 223-242.

110 Weiss-Wendt, op. cit., pp. 114-129. Lukina, op. cit. 
«ideological pragmatism» that transformed well-entrenched elements of the domestic legal order into rhetorical weapons to be used against its chief opponents in the incipient Cold War - and turned a convenient blind eye on domestic violations of the very same ideological principles defended in Paris.

As the current historiography has neglected the support for collective rights in both the GC and the UDHR debates, it has tended to overemphasise the collective-right nature of the interwar minority treaties and to overlook the provisions concerning all citizens and inhabitants contained within these treaties. A more nuanced account of the transition from the League's to the UN's system ought to recognise the ambivalent legacy of minority protection for human rights, including not only the obvious drawbacks of the interwar minority system - which however still contributed to influence the organisation of the UN rights system in universal terms -, but also its overlooked potential. The references to non-discrimination and the right to life and liberty existing in the Polish Treaty were exploited by interwar rights advocates to propose an extension of the protection offered by the minority treaties into more comprehensive human rights instruments.

Among interwar international lawyers, André Mandelstam was the most active supporter of a transition from the regional human law (as he defined it) that had been ushered in by the minority treaties to a universal human rights system. Mandelstam died in 1949, but had already been confined to the margins of international debates after his defence of the Italian invasion of Ethiopia in 1937. Albert de la Pradelle and Boris Mirkine-Guetzévitch, two of Mandelstam's colleagues who had most strongly defended the recognition of the individual as a subject of international law during the interwar years, passed away in 1955. They could not, therefore, have a lasting impact on the new rights system that was being devised in the post-war years. However, in 1951, commenting on the Covenant on Human Rights then under discussion at the United Nations Commission on Human Rights (CHR), Mirkine-Guetzévitch reaffirmed the value of the minorities treaties for the future of human rights. He argued that the CHR's proposals were «a regression on the procedures for protection of human rights established after the WWI» and recommended the CHR to draw inspiration from the "minority treaties concluded after 1918». ${ }^{111}$ Despite the minorities treaties' obvious flaws and ambivalent legacy, neglecting their potential for human rights conveys an unwarranted view of interwar minority protection as incompatible with the post- 1945 human rights system.

While it is certainly true that in the post-WWII period human rights became the prevalent «international law fashion», ${ }^{112}$ collective understandings of

111 Boris Mirkine-Guetzévitch, L’ONU et la doctrine moderne des Droits de l'Homme, in: Revue Générale de Droit International Public 55/2 (1951), pp. 161-198.

112 Josep Kunz quoted in Mazower, The Strange, op. cit., p. 398. 
rights did not disappear. The idea that an individualist conception of human rights unanimously carried the day in the late 1940s betrays a Western bias, since a substantial part of the non-Western world supported a vision of rights that included articles targeting specific categories of individuals. ${ }^{113}$ Furthermore, as our analysis of the debates on cultural genocide in the negotiations for the GC and on protection against assimilation within the framework of the drafting of the UDHR reveals, the main line of fracture dividing UN delegates during those discussions reflected a clash between supporters of assimilation and defenders of the preservation of the cultural specificities of minority groups. Hence, the «triumph» of human rights after 1945 was «strange» in two ways: it did not seriously restrain state sovereignty (as Mark Mazower has correctly pointed out); and it furthered an assimilationist interpretation of rights that in a context of national heterogeneity promised to favour the rights of some groups (national majorities) over those of others (national minorities).

Emmanuel Dalle Mulle, Graduate Institute of International and Development Studies: Institut de Hautes Etudes Internationales et du Développement, Albert Hirschman Centre on Democracy, Chemin Eugène-Rigot 2a, 1211 Geneva, emmanuel.

dallemulle@graduateinstitute.ch

Mona Bieling, Graduate Institute of International and Development Studies: Institut de Hautes Etudes Internationales et du Développement, Chemin Eugène-Rigot 2a, 1211 Geneva, mona.bieling@graduateinstitute.ch

113 For Soviet continuous defence of such rights in international forums in the 1950s and 1960s see Eric Weitz, A World Divided: The Global Struggle for Human Rights in the Age of Nation-States, Princeton 2019, pp. 281-319. 